\author{
DOI: $10.26693 / \mathrm{jmbs} 06.05 .370$ \\ UDC $613.83(477)=111$ \\ Khrypunova Tetiana
}

\title{
Relationships between the Ukrainian Public's Awareness of Psychotropic Drugs, Stigmatizing People Taking Psychotropic Drugs and Stopping Psychotropic Drug Medication without Consulting with a Doctor
}

\author{
University of Medicine in Prague, Czech Republic
}

The purpose of the study was to outline possible relationships between public awareness of psychotropic drugs, stigmatization of people suffering from mental disorders and discontinuation of drugs without consultation with a doctor in Ukraine.

Materials and methods. This study is based on the analysis of data obtained through an electronic questionnaire filled out by the Ukrainian public. Until April 2021 the questionnaire was freely available to everyone who wanted to take part in the survey. The questionnaire was distributed via an Internet link. Based on the obtained data, the respondents were divided into different categories depending on their education, profession (a medical worker was analyzed separately). Also, the respondents who had personal experience of using psychotropic drugs were interviewed especially deeply and in more details, depending on which group of drugs they used (antidepressants / antipsychotics / anxiolytics). The separate place in the study was given to identifying the general awareness of the Ukrainian public about correct and erroneous judgments about psychotropic drugs.

Results and discussion. Based on the obtained data, main factors which are influencing people awareness of psychotropic drugs were identified, as well as the approximate percentage of citizens with erroneous judgments about psychotropic drugs. Thanks to the results of the questionnaire, the main possible reasons for the withdrawal of treatment with psychotropic drugs by patients without consultation with the attending physician were suggested (identified).

Conclusion. It can be concluded from the obtained data that a person's awareness in the field of psychotropic drugs is most influenced by their own experience of their use. For this reason, the author would be interested to know how psychiatric patients are informed by their physicians. The author is aware that the amount of data obtained is not completely sufficient to create a significant picture of the general situation, but she hopes that the obtained data will still allow to get some idea of the situation as a whole. In conclusion, not only the obtained results in this study were outlined, but also possible further actions to obtain a more accurate picture of the situation were mentioned, and the topic of the next study was indicated in order to solve the identified problem.

Keywords: Ukraine, psychotropic drugs, discontinuation of drugs, stigmatization, awareness of psychotropic drugs.

Introduction. The introduction of psychotropic drugs into clinical practice has been marked as a breakthrough in psychiatry, and since then new, more modern preparations have been appearing on the market, enabling increasingly effective treatment. On the other hand, even today, the stigmatization of people suffering from mental disorders persists and many patients discontinue prescribed drugs without consulting their doctor.

The purpose of the study. In this work, we aim to outline possible relationships between public awareness of psychotropic drugs (hereinafter referred to as awareness), stigmatization of people suffering from mental disorders (hereinafter referred to as stigmatization) and discontinuation of drugs without consultation with a doctor (hereinafter non-adherence) in Ukraine. However, the most space of this article is devoted to possible causes of non-adherence.

Links:

1. https://med-luban.by/polinform/307-chto-takoe-stigma-stigmatizatsiya-samostigmatizatsiya-i-kak-ee-izbezhat.html

2. https://www.healthline.com/health/what-is-apsychotropic-drug

3. https://scielo.isciii.es/scielo.php?script=sci arttext\&pid=S0213-61632012000400003 
Materials and methods. This work is based on the data provided in the questionnaire, which was shared via an Internet link. The link was first shared among users of the social network Facebook, later shared by the Depression \& Hope page, and after was shared among users of the social network VKontakte. 462 responses were received, 3 of which were excluded because the answer of the respondent age was not realistic, so these responses were considered as irrelevant. Due to the method of distributing the questionnaire, it was not possible to obtain a representative sample of respondents for the total population of Ukraine. Only about $22 \%$ of respondents were men, the average age of the respondent was 28 years old and almost $35 \%$ of respondents work or study in the medical field. Then the answers were sorted into different categories and were compared according to the goals of this work. The categories were mainly based on experience with psychotropic drugs and medical education.

Representation of health professionals among respondents

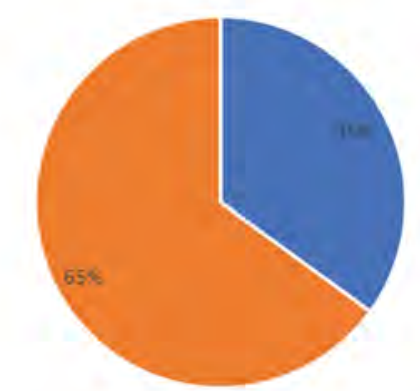

- Medical professions = Other than medical field

\section{Distribution of respondents by education}

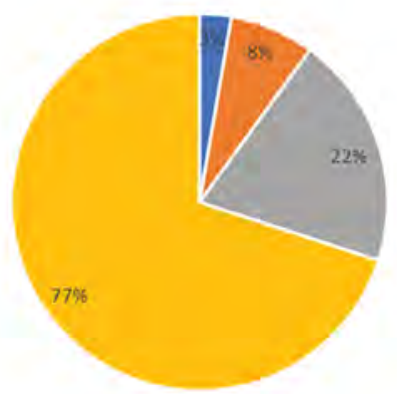

- Primary school - High school "Colleges/Lyceums = University graduation

Results. We obtained the largest differences in the answers when divided according to the respondents' experience with psychotropic drugs. The best informed were those who were at that moment taking psychotropic drugs, slightly less those who had been taking them, but who had discontinued them in collaboration with a doctor. Respondents who discontinued medication without consulting a physician were less informed than those who discontinued medication in collaboration with a physician. The least informed were those who had never taken psychotropic drugs.

There were also some differences between the responses of men and women and between health professionals and lay people. However, these differences were not very significant compared to the above distribution. This can be evidenced by the fact that in the group of people who have never used psychotropic drugs, $42 \%$ are health professionals and in the group of people who are currently taking psychotropic drugs, only $10 \%$, and yet the answers show a significant impact of their own experience on information.
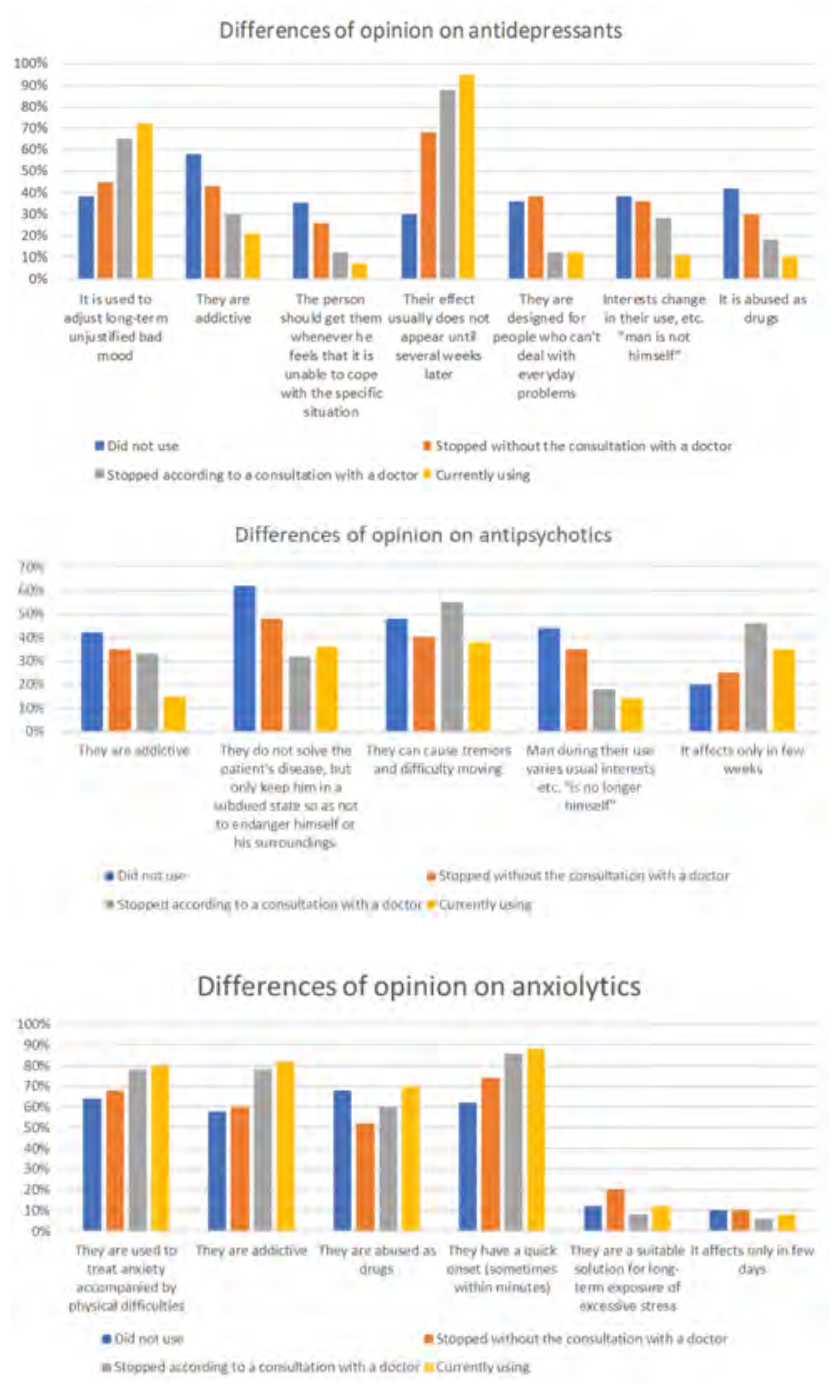

We also got an overview of how often patients stop taking psychotropic drugs and for what reason. Of those who reported experience with antidepressants (136 people in total), $67 \%$ are currently taking them, $10 \%$ have discontinued them in collaboration with a doctor and $23 \%$ have discontinued them without consulting a doctor. Of those who reported experience with the use of antipsychotics (a total of 41 people), $63 \%$ are currently taking it, $7 \%$ have discontinued it in cooperation with a doctor and $30 \%$ have 
discontinued it without consulting a doctor. Of those who reported experience with the use of anxiolytics (a total of 80 people), $50 \%$ are currently taking it, $14 \%$ have discontinued it in cooperation with a doctor and $36 \%$ have discontinued it without consulting a doctor.

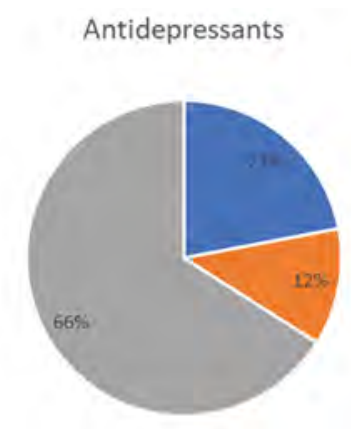

- Stopped without the consultation with a doctor $=$ Stopped with the consultation with a doctor "Currently using

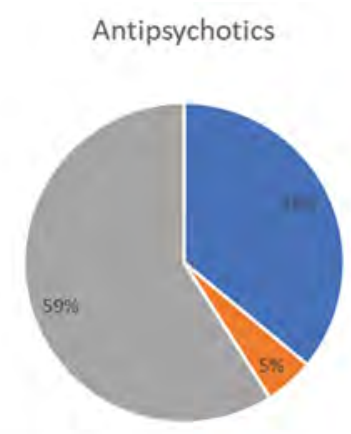

- Stopped without the consultation with a doctor $\mathrm{n}$ Stopped with the consultation with a doctor = Currently using

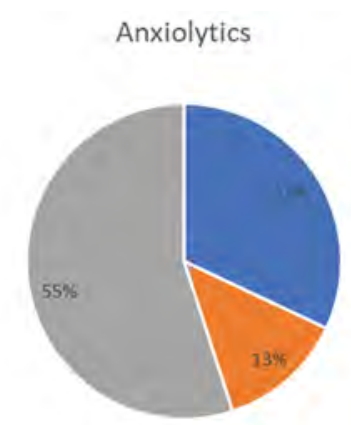

- Stopped without the consultation with a doctor a Stopped with the consultation with a doctor " Currently using

Respondents who discontinued medication without consultation (72 people were able to provide multiple responses) did not state a reason in 18 cases. Others cited side effects in 10 cases, in 9 cases improved mental state, in 8 cases they tried to minimize the amount of drugs used, in 8 cases they indicated the inability to cooperate with the doctor (antipathy, forgot to use, after taking the package they did not visit the doctor, etc.), in 7 cases they stated that they did not observe any effect, in 6 cases they were convinced that the drug changed their personality, in 4 cases they stated fear of addiction, in 2 cases preg- nancy and no one stated as a reason for the reaction of the environment or persuasion of others.

\section{Reasons for discontinuation without consulting a doctor}

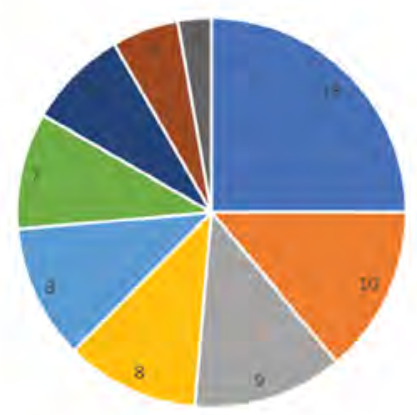

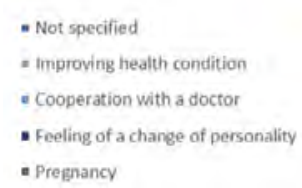

- Not specified

- Improving health condition

- Cooperation with a doctor

- Feeling of a change of personality

- Pregnancy

- Efforts to mirimize the amount of used drugs

- No improvenent of health condition

- Fear of addiction
- Side effects

Respondents did not comment much on openly stigmatizing views. Only $5 \%$ of respondents considered the use of psychotropic drugs as a manifestation of weakness or incapacity, $4 \%$ of respondents considered persons taking psychotropic drugs to be dangerous and $1 \%$ of respondents described persons taking psychotropic drugs as fools. Respondents most often identified people using psychotropic drugs as ill in $80 \%$ of responses, and $60 \%$ of respondents consider the use of psychotropic drugs to be the result of exposure to excessive stress. A possible connection with non-adherence emerged in these opinions. Respondents who discontinued psychotropic drugs without consulting a physician considered those who use psychotropic drugs to be ill in $69 \%$ of cases (least of all groups) and respondents who discontinued psychotropic drugs in cooperation with a physician considered persons who use psychotropic drugs to be ill in $88 \%$ of cases (most of all groups).

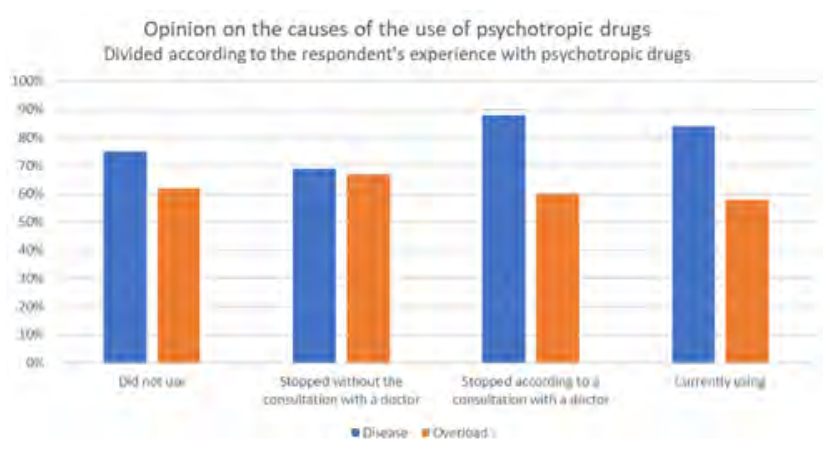

Two indirectly stigmatizing statements were hidden in the questionnaire in possible questionnaires. The first is about antidepressants, and it says, "They are for people who cannot deal with everyday problems", and attributes weakness or disability to people taking antidepressants. This statement was signed as 
a true one by $14 \%$ of all respondents and in the group of respondents who stopped psychotropic drugs without consulting a doctor, even $28 \%$. The second statement, which concerned antipsychotics, was "They do not solve the patient's illness, but only keep the patient in a subdued state so as not to endanger himself or his surroundings". This statement was signed as a true one by $44 \%$ of all respondents and $56 \%$ of the group of respondents who discontinued psychotropic drugs without consulting a doctor.

About $20 \%$ of respondents appear to believe that psychotropic drugs in general are misused for recreational purposes. More specifically, in the case of antidepressants it is $23 \%$ of respondents and in the case of antipsychotics $19 \%$ of respondents.

Discussion. This work outlines possible relationships in the issue under study, but the relatively small number of respondents and their unrepresentative composition does not allow making absolutely substantiated statements about the situation in Ukraine on the basis of these data. Therefore, the author considers it useful to repeat this survey on a larger number of respondents with a representative composition.

Due to the dissemination method (described in the chapter named "Materials and methods"), the questionnaire was probably completed mainly by people who are significantly more interested in the issue, which may influence the survey results. Another difficulty arising from the way the questionnaire was distributed is the lack of any feedback on how seriously the respondents approached the questionnaire.

Links:

1. https://scielo.isciii.es/scielo.php?script=sci arttext\&pid=S0213-61632012000400003

2. https://pubmed.ncbi.nIm.nih.gov/1535931/
Conclusion. From the obtained data, it can be concluded that a person's awareness in the field of psychotropic drugs is most influenced by their own experience of their use. For this reason, the author would be interested to know how psychiatric patients are informed by their physicians.

In the case of non-adherence to treatment, the author came to two possible reasons. One of them may be the perception of the use of psychotropic drugs as a manifestation of one's own weakness or inability to independently cope with the routine daily aspects of life. Another likely reason is the lack of mutual understanding and awareness on the part of the attending physician.

Perspectives of further research. Based on the second reason for non-adherence with the patient's treatment, which is insufficient patient awareness or insufficient understanding between the patient and the attending physician, the author would like to specify more clearly and narrow the field of further research.

The author singles out the main area of activity of the analysis of psychiatrists' and psychotherapists' work during the consultation of patients. The main topic will be the study of the availability and depth of information offered to patients by the attending physician. The main purpose of this study will be to evaluate and offer recommendations to both parties to solve the problem and to inform patients better, first of all, about their health situation and the importance of treatment. Undoubtedly, the questions of cancellation or replacement of drugs will also be raised, but under the strict supervision of the attending physician.

Also, the author aims to raise awareness of the healthy part of the Ukrainian public about psychotropic drugs and dispel well-established erroneous judgments and myths about them.

\section{References}

1. What Is a Psychotropic Drug? Available from: https://www.healthline.com/health/what-is-a-psychotropic-drug

2. Boelman L, Smeets HM, Knol MJ, Braam AW, Geerlings MI, de Wit NJ. Psychotropic drug use in patients with various chronic somatic diseases. Eur J Psychiat. 2012 26(4). doi: 10.4321/S0213-61632012000400003

3. Psykhotropnye lekarstvennye sredstva [Psychotropic medicines]. [Russian]. Available from: https://gxpnews. net/terminologiya/psixotropnye-lekarstvennye-sredstva/

4. Rasshyrenye dostupnosty psykhotropnykh sredstv y uluchshenye praktyky ykh yspolzovanyya [Expanding the availability of psychotropic agents and improving the practice of their use]. [Russian]. Available from: https:// www.who.int/mental_health/policy/lmproving\%20Access $\% 20$ and $\% 20$ Use $\% 20$ of $\% 20$ Psychotropic\%20Medicines_ru.pdf

5. Faktory styhmatyzatsyy lyts s psykhycheskymy rasstroystvamy [Factors of stigmatization of persons with mental disorders]. [Russian]. Available from: http://www.psychiatry.ru/siteconst/userfiles/psystigm.pdf

6. Chto takoe styhma, styhmatyzatsyya, samostyhmatyzatsyya y kak ee yzbezhat [What is stigma, stigmatization, samstygmatization and how to avoid it]. [Russian]. Available from: https://med-luban.by/polinform/307-chto-takoe-stigma-stigmatizatsiya-samostigmatizatsiya-i-kak-ee-izbezhat.html

7. 3D printing of diazepam-containing pharmaceutical forms for the treatment of patients addicted to benzodiazepines. Available from: https://angeliniaward.cz/en/2018-2019-edition/

8. Brust JC. Neurological complications of substance abuse. Res Publ Assoc Res Nerv Ment Dis. 1992;70:193203. PMID: 1535931 
Удк 613.83(477)=111

ОТНОШЕНИЯ МЕЖДУ ОСВЕДОМЛЕННОСТЬЮ УКРАИНСКОЙ ОБЩЕСТВЕННОСТИ О ПСИХОТРОПНЫХ ПРЕПАРАТАХ, СТИГМАТИЗАЦИИ ПАЦИЕНТОВ, ПРИНИМАЮЩИХ ПСИХОТРОПНЫЕ ПРЕПАРАТЫ, И ПРЕКРАЩЕНИЕМ ПРИЕМА ПСИХОТРОПНЫХ ПРЕПАРАТОВ БЕЗ КОНСУЛЬТАЦИИ С ЛЕЧАЩИМ ВРАЧОМ Хрипунова Татьяна

Резюме. Целью работы явилось исследование взаимосвязи между осведомленностью украинской общественности о психотропных препаратах, стигматизацией пациентов, употребляющих психотропные препараты, и прекращением приема психотропных препаратов пациентами без консультации с лечащим врачом.

Материал и методы. Данное исследование основано на анализе данных, полученных посредством электронной анкеты, заполняемой украинской общественностью, и до апреля 2021 года находившейся в свободном доступе для всех желающих принять участие в анкетировании через интернетссылки.

На основании полученных данных, респонденты были разделены по различным категориям в зависимости от их образования, профессии (отдельно были проанализированы работники медицинских специальностей). Респонденты, имеющие личный опыт использования психотропных препаратов, были опрошены более подробно, в зависимости от того, какую группу лекарств они использовали (антидепрессанты / антипсихотики / анксиолитики). Отдельное место в исследовании заняло выявление общей осведомленности украинской общественности о верных и ошибочных суждениях о психотропных препаратах.

Результаты. Наибольшие различия в ответах были получены при разделении респондентов согласно опыта применения психотропных препаратов - принимающих препараты; прекративших прием в сотрудничестве с врачом; прекратив самостоятельно; никогда не принимавшие психотропные препараты. Были также различия между ответами мужчин и женщин, а также между медицинскими работниками и непрофессионалами в медицинской сфере.

На основании полученных данных были определены основные фракторы, которые влияют на осознание людей о психотропных препаратах, а также приблизительный процент граждан с ошибочными суждениями о них. Благодаря результатам анкеты были определены основные возможные причины прекращения пациентами лечения психотропными препаратами без консультаций с лечащим врачом.

Выводы. Отношение человека к психотропным препаратам чаще формируется на собственном опыте применения - как проявление собственной слабости или неспособности самостоятельно справляться с рутинными повседневными аспектами жизни, а также недостаточном взаимопонимании и информированности со стороны лечащего врача.

Ключевые слова: Украина, психотропные препараты, отказ от медикаментов, стигматизация, осведомленность о психотропных средствах.

Удк 613.83(477)=111

ВІДНОСИНИ МІЖ ОБІЗНАНІСТЮ УКРАЇНСЬКОЇ ГРОМАДСЬКОСТІ

ПРО ПСИХОТРОПНІ ПРЕПАРАТИ, СТИГМАТИЗАЦІЇ ПАЦІЄНТІВ,

ЯКІ ПРИЙМАЮТЬ ПСИХОТРОПНІ ПРЕПАРАТИ, І ПРИПИНЕННЯ ПРИЙОМУ

ПСИХОТРОПНИХ ПРЕПАРАТІВ БЕЗ КОНСУЛЬТАЦІЇ 3 ЛІКАРЕМ

Хрипунова Тетяна

Резюме. Метою роботи було вивчення взаємозв'язку між поінформованістю української громадськості про психотропні препарати, стигматизацією пацієнтів, що вживають психотропні препарати, та припиненням прийому психотропних препаратів пацієнтами без консультації з лікарем.

Матеріал та методи. Дане дослідження засноване на аналізі даних, отриманих за допомогою електронної анкети, що заповнювалась українською громадськістю, і до квітня 2021 роки перебувала в вільному доступі для всіх бажаючих взяти участь в анкетуванні через інтернет-посилання.

На підставі отриманих даних респонденти були розділені на різні категорії залежно від їх освіти, професії (окремо були проаналізовані працівники медичних спеціальностей). Респондентів, які мали особистий досвід використання психотропних препаратів, було опитано більш докладно, в залежності від того, яку групу ліків вони використовували (антидепресанти / антипсихотики / анксіолитики). Окреме місце в дослідженні зайняло виявлення загальної поінформованості української громадськості про вірні та помилкові судження про психотропні препарати. 
Результати. Найбільші відмінності у відповідях були отримані при поділі респондентів згідно досвіду застосування психотропних препаратів - тих, хто приймають препарати; які припинили прийом у співпраці з лікарем; припинивши самостійно; ніколи не приймали психотропні препарати. Були також відмінності між відповідями чоловіків і жінок, а також між медичними працівниками і непрофесіоналами в медичній сорері.

На підставі отриманих даних було визначено основні чинники, які впливають на усвідомлення людей про психотропні препарати, а також приблизний відсоток громадян з помилковими судженнями про них. Завдяки результатам анкети були визначені основні можливі причини припинення пацієнтами лікування психотропними препаратами без консультацій з лікарем.

Висновки. На необізнаність людини в області психотропних препаратів найбільше впливає власний досвід їх використання - як прояв власної слабкості або нездатності самостійно справлятися з рутинними повсякденними аспектами життя, а також недостатнє взаєморозуміння та інформованість з боку лікаря.

Ключові слова: Україна, психотропні препарати, відмова від медикаментів, стигматизація, обізнаність про психотропних засобах.

\section{ORCID and contributionship:}

Tetiana Khrypunova : 0000-0003-4344-013X A-F

A - Work concept and design, B - Data collection and analysis,

C - Responsibility for statistical analysis, D - Writing the article,

$\mathrm{E}$ - Critical review, F - Final approval of the article

\section{CORRESPONDING AUTHOR}

Tetiana Khrypunova

University of Medicine in Prague

1094, Duškova, 5-Smíchov, Praha 15000, Czech Republic

tel: +420728248903, e-mail: tanyatatatata@yandex.ua

The authors of this study confirm that the research and publication of the results were not associated with any conflicts regarding commercial or financial relations, relations with organizations and/or individuals who may have been related to the study, and interrelations of coauthors of the article.

Стаття надійшла 19.08.2021 p.

Рекомендована до друку на засіданні редакційної колеаії після рецензування 